\title{
Consistent relationship between global climate and surface nitrate utilization in the western subarctic Pacific throughout the last $500 \mathrm{ka}$
}

\author{
Eric D. Galbraith, ${ }^{1,2}$ Markus Kienast, ${ }^{3}$ Samuel L. Jaccard, ${ }^{4}$ Thomas F. Pedersen, ${ }^{5}$ \\ Brigitte G. Brunelle, ${ }^{6}$ Daniel M. Sigman, ${ }^{6}$ and Thorsten Kiefer $^{7}$
}

Received 3 July 2007; revised 11 December 2007; accepted 8 January 2008; published 23 May 2008.

[1] The open subarctic Pacific is, at present, a high nitrate low chlorophyll (HNLC) region, where nitrate is perennially abundant at the surface. Theoretically, the HNLC status of this region is subject to modification by ocean circulation and/or micronutrient supply, with implications for the effectiveness of the biological pump and hence carbon sequestration in the ocean interior. Records of biogenic detritus in sediments from throughout the subarctic Pacific indicate that export production was generally lower during glacial maxima, while nitrogen isotope measurements from the Bering Sea have shown that nitrate consumption there was more complete during the last glacial period than it is today. Here, nitrogen isotopic analyses of bulk sediments $\left(\delta^{15} \mathrm{~N}_{\text {bulk }}\right)$ from three deep water sites in the open subarctic Pacific are evaluated in terms of regional nitrate isotopic composition and local relative nitrate utilization. The eastern subarctic Pacific $\delta^{15} \mathrm{~N}_{\text {bulk }}$ record bears great similarity to $\delta^{15} \mathrm{~N}_{\text {bulk }}$ records from the western margin of North America over the last glacial cycle, suggesting that variability in the isotopic composition of subeuphotic zone nitrate, the growth substrate, is reasonably coherent throughout the northeast Pacific and dominates at these sites. However, the two western subarctic Pacific records, which lie at the heart of the HNLC region, display a different pattern, implying that significant changes in local relative nitrate utilization overlie the regional background variability. After a novel correction intended to remove the background signal associated with denitrification in the eastern tropical North Pacific, these nitrate utilization records are correlated with a benthic oxygen isotope stack reflecting global deep ocean temperature and ice volume $\left(r^{2}=0.65\right)$. The correlation implies a strong link between global climate and subarctic Pacific nitrate utilization, with nearly complete nitrate consumption during glacial periods when export production was low.

Citation: Galbraith, E. D., M. Kienast, S. L. Jaccard, T. F. Pedersen, B. G. Brunelle, D. M. Sigman, and T. Kiefer (2008), Consistent relationship between global climate and surface nitrate utilization in the western subarctic Pacific throughout the last 500 ka, Paleoceanography, 23, PA2212, doi:10.1029/2007PA001518.

\section{Introduction}

[2] Sedimentary records have demonstrated an intimate link between past changes in global climate and the biogeochemical dynamics of the subarctic Pacific [e.g., Haug et al., 1999; Sancetta and Silvestri, 1984]. Perhaps most notably, the accumulations of biogenic opal and $\mathrm{Ba}$ in subarctic sediments were significantly lower during globally

\footnotetext{
${ }^{1}$ Department of Earth and Ocean Sciences, University of British Columbia, Vancouver, British Columbia, Canada.

${ }^{2}$ Now at Department of Geosciences, Princeton University, Princeton, New Jersey, USA.

${ }^{3}$ Department of Oceanography, Dalhousie University, Halifax, Nova Scotia, Canada.

${ }^{4}$ Geological Institute, Department of Earth Sciences, Eidgenossische Technische Hochschule Zurich, Zurich, Switzerland.

${ }^{5}$ School of Earth and Ocean Sciences, University of Victoria, Victoria, British Columbia, Canada.

${ }^{6}$ Department of Geosciences, Princeton University, Princeton, New Jersey, USA.

${ }^{7}$ Past Global Changes International Project Office, Bern, Switzerland.

Copyright 2008 by the American Geophysical Union. 0883-8305/08/2007PA001518
}

cold periods, and show remarkable correlations with Antarctic temperatures on glacial-interglacial timescales [Jaccard et al., 2005; Kienast et al., 2004; Narita et al., 2002; Nürnberg and Tiedemann, 2004; Shigemitsu et al., 2007]. Although debate persists on the characteristics of productivity changes across glacial terminations (H. Gebhardt et al., Paleonutrient and productivity records from the subarctic North Pacific for Pleistocene glacial terminations I to V, submitted to Paleoceanography, 2007, hereinafter referred to as Gebhardt et al., submitted manuscript, 2007), most authors have interpreted the paleoproduction proxies as indicating a positive correlation between high-latitude temperature and export production in the subarctic Pacific. In addition, Brunelle et al. [2007] have used nitrogen isotopic measurements to argue that in the Bering Sea, where nitrate concentrations are now perennially high (Figure 1), nitrate utilization was more complete during the last glacial period. Mechanisms that might explain aspects of these observed relationships have been suggested, including the alleviation of iron limitation by enhanced glacial dust flux [Martin, 1990] and a decrease of nutrient supply due to reduced exchange between surface 


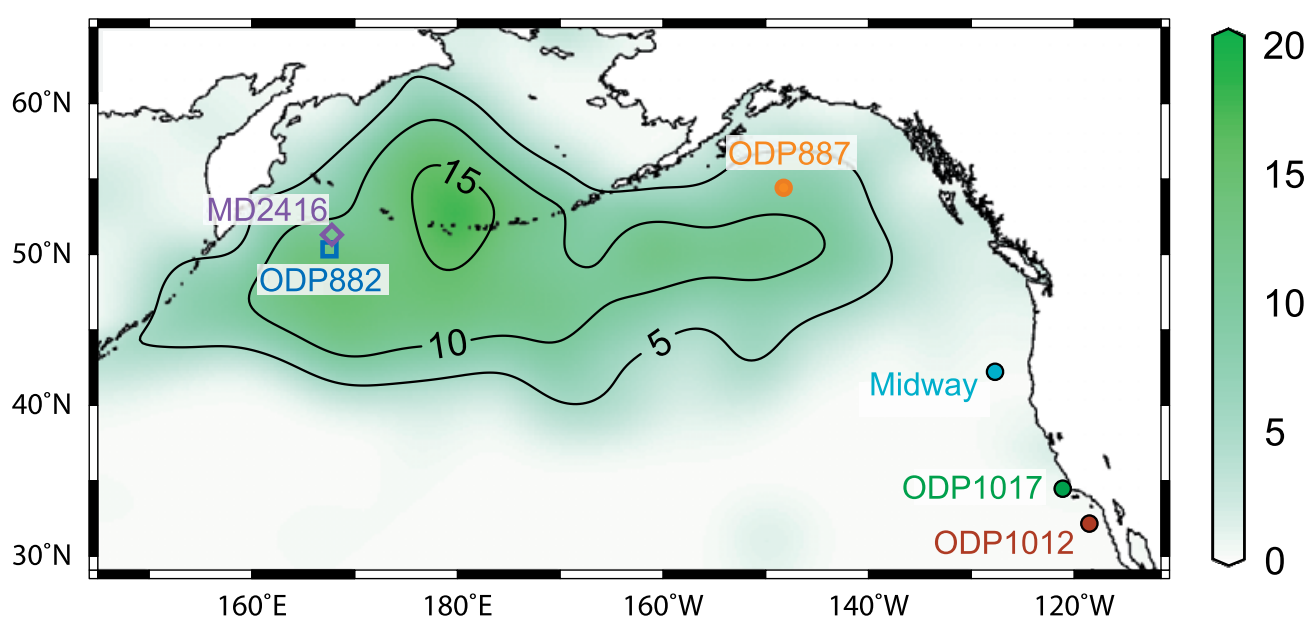

Figure 1. Summer nitrate concentrations at the subarctic Pacific surface. Average nitrate concentrations are shown for the sea surface in July-September by color shading and contour lines, labels in $\mu \mathrm{M}$ [Conkright et al., 2002]. The locations of ODP site $887\left(54.37^{\circ} \mathrm{N}, 148.45^{\circ} \mathrm{W}, 3647 \mathrm{~m}\right)$, ODP site $882\left(50.35^{\circ} \mathrm{N}, 167.58^{\circ} \mathrm{E}, 3244 \mathrm{~m}\right)$, and $\operatorname{MD} 2416\left(51.27^{\circ} \mathrm{N}, 167.73^{\circ} \mathrm{E}, 2317 \mathrm{~m}\right)$ are given by the solid circle, open square, and open diamond, respectively. Also shown are sites ODP $1012\left(32.28^{\circ} \mathrm{N}\right.$, $\left.118.40^{\circ} \mathrm{W}, 1772 \mathrm{~m}\right)$, ODP $1017\left(34.53^{\circ} \mathrm{N}, 120.10^{\circ} \mathrm{W}, 955 \mathrm{~m}\right)$, and the multitracers Midway site $\left(42.26^{\circ} \mathrm{N}, 127.68^{\circ} \mathrm{W}, 2317 \mathrm{~m}\right)$, all of which are discussed in the text.

and subsurface waters [Jaccard et al., 2005]. However, the general relationships between the subarctic Pacific ecosystem and global climate remain equivocal [Kienast et al., 2004].

[3] Here, new data are presented from three core sites located on seamounts at 2.3 to $3.6 \mathrm{~km}$ water depth (Figure 1) in order to investigate the past nitrogen isotope dynamics of the open subarctic Pacific. We use the isotopic composition of nitrogen protected by diatom frustules to evaluate the impact of diagenesis on bulk combustible N. Subsequently, we compare the bulk $\mathrm{N}$ isotopic measurements to previously published records from elsewhere in the North Pacific. This comparison leads us to introduce a novel correction, intended to eliminate multimillennial temporal changes in the isotopic balance of the North Pacific wrought by variable denitrification. The residual is interpreted to vary as a function of relative nitrate utilization, i.e. the fraction of upwelled nitrate that is consumed on an annual basis. The results reveal a remarkably consistent link between global climate and relative nitrate utilization at the subarctic Pacific surface.

\section{Methods}

[4] The new measurements presented here were made on three deep-sea sediment cores from the subarctic Pacific (Figure 1). The sites are all located on the flanks of seamounts, well above the turbidite fans that blanket much of the North Pacific seafloor. The eastern site (ODP 887) lies on the Patton-Murray seamounts, $\sim 300 \mathrm{~km} \mathrm{SE}$ of the broad Alaskan Shelf, beneath the Alaska Gyre [Whitney et al., 2005]. The two western sites (ODP 882 and MD 2416) lie $>500 \mathrm{~km} \mathrm{SE}$ of the narrow Kamchatka shelf, on opposite sides of the Detroit Seamount, beneath the domal upwelling of the western subarctic Gyre. All cores consist of hemi- pelagic sediment with highly variable abundances of biogenic detritus, ice rafted debris, and fine mud. Carbonate preservation in all cores is sporadic and strongly related to climate cycles [Jaccard et al., 2005; Gebhardt et al., submitted manuscript, 2007].

[5] Diatoms were separated from decarbonated bulk sediments by flotation in a dense solution of sodium polytungstate, following Sigman et al. [1999a] as described by Galbraith [2006]. Unprotected N was removed by oxidation in perchloric acid as described by Brunelle et al. [2007], and diatom-bound ${ }^{15} \mathrm{~N} /{ }^{14} \mathrm{~N}$ was measured at Princeton University using the persulfate-denitrifier method [Robinson et al., 2004]. While no replicate analyses were made for this study, previous work showed a standard deviation among replicates of $0.3 \%$ o $(1 \sigma)$ [Brunelle et al., 2007]. For bulk measurements, fresh samples were freeze-dried and thoroughly ground in an agate mortar to ensure homogenization. The ${ }^{15} \mathrm{~N} /{ }^{14} \mathrm{~N}$ was measured at the University of British Columbia by combustion using a Carlo Erba NC 2500 elemental analyzer coupled to a Finnigan Mat Delta Plus mass spectrometer, via a Finnigan Mat ConFlo III. All ${ }^{15} \mathrm{~N} /{ }^{14} \mathrm{~N}$ measurements are reported as $\delta^{15} \mathrm{~N}=$ $\left(\left({ }^{15} \mathrm{~N} /{ }^{14} \mathrm{~N}\right)_{\text {sample }} /\left({ }^{15} \mathrm{~N} /{ }^{14} \mathrm{~N}\right)_{\text {air }}-1\right) * 1000 \%$. The standard deviation of repeat bulk measurements was approximately $0.3 \%$ o $(1 \sigma)$.

[6] The age model for ODP site 887 is based on twelve calibrated radiocarbon ages over the past $25 \mathrm{ka}$, measured on mixed planktonic foraminifera (dominated by Globigerina bulloides and Neogloboquadrina pachyderma) as discussed by Galbraith et al. [2007]. The ages of older sediments were estimated by visual correlation of benthic foraminiferal $\delta^{18} \mathrm{O}$ (from McDonald [1997]) to the benthic stack of Lisiecki and Raymo [2005], as shown in Figure 2 and described by Galbraith [2006]. The age model for ODP site 882 was generated by correlating high-resolution XRF 


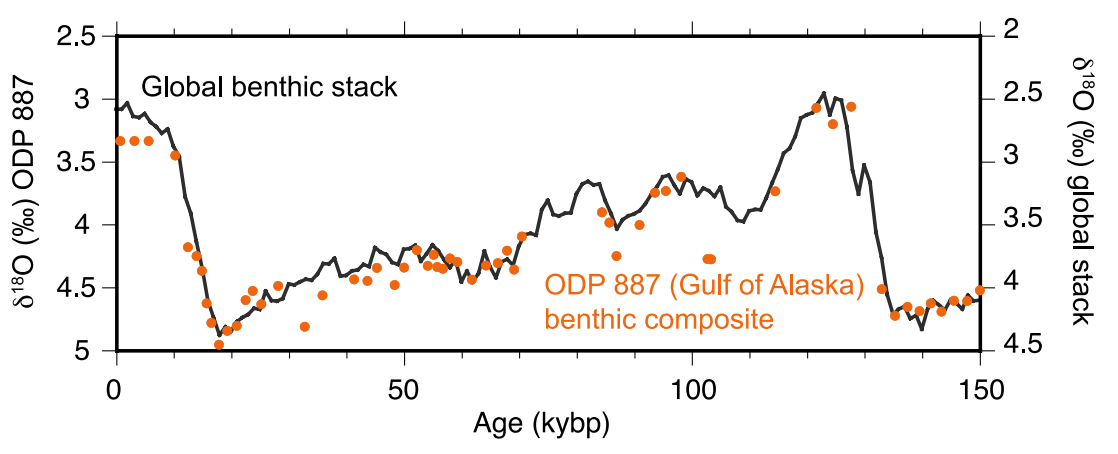

Figure 2. Benthic oxygen isotope stratigraphic control for ODP site 887. Shown are a global benthic stacked record [Lisiecki and Raymo, 2005] (gray line) and the ODP 887 multispecies benthic isotope measurements of McDonald [1997] (orange circles).

scanner $\mathrm{Ba} / \mathrm{Al}$ measurements to the the Vostok $\mathrm{dD}$ record over the past $150 \mathrm{ka}$, as described by Jaccard et al. [2005], modified over the most recent $30 \mathrm{ka}$ to incorporate two planktonic foraminifera radiocarbon ages [Galbraith et al., 2007]. The $\mathrm{Ba} / \mathrm{Al}$ correlation to Antarctic temperature was extended prior to $150 \mathrm{ka}$ by tying the calculated ODP 882 $\mathrm{Ba} / \mathrm{Al}$ record to the European Project for Ice Coring in Antarctica (EPICA) $\delta \mathrm{D}$ record at 16 additional points (Figure 3). Given that Ba measurements were not available for MD2416, the age model was generated by correlating high-resolution XRF scanner $\mathrm{Ca}$ measurements between ODP 882 and MD2416 (Figure 3). The resulting age-depth relationships are shown in Figure 4. We note that Gebhardt et al. (submitted manuscript, 2007) use an alternate age model, with significantly larger variations in sedimentation rate. These variations are caused by the use of many more stratigraphic tie points, that were drawn by visual correlation of down core ${ }^{14} \mathrm{C}$ records to the reconstructed atmospheric ${ }^{14} \mathrm{C}$ history [Sarnthein et al., 2004, 2007], and by correlating magnetic paleointensity and benthic $\delta^{18} \mathrm{O}$ records to various reference curves [Kiefer et al., 2001; Sarnthein et al., 2005, 2006]. In order to obtain maximum chronological consistency between the cores used for this study (including previously published records) we use only the minimally constrained, EPICA-based age model here. However, our general results are consistent with both MD2416 age models.

\section{Sources of N Isotope Variability}

\subsection{Diagenesis}

[7] The primary measurement used here is the ${ }^{15} \mathrm{~N} /{ }^{14} \mathrm{~N}$ of combustible nitrogen in bulk sediment, designated $\delta^{15} \mathrm{~N}_{\text {bulk }}$. We assume that, at our deep-sea sites, this measurement includes very little inorganic and terrestrial nitrogen, and is therefore representative of marine organic $\mathrm{N}$ exported from the subarctic surface. Sediments on continental slopes commonly record the $\delta^{15} \mathrm{~N}$ of exported marine organic matter with little "diagenetic" isotopic alteration during sinking and sedimentation [Altabet et al., 1999; Ganeshram et al., 2000; Thunell et al., 2004]. However, it is generally thought that diagenetic alteration is more pronounced in deep-sea sediments, such as those presented here.
Therefore, our first concern is to address the possibility that diagenesis plays a strong role in our down core records. In order to gauge the degree to which the $\delta^{15} \mathrm{~N}_{\text {bulk }}$ may diverge from the $\delta^{15} \mathrm{~N}$ of phytoplankton exported from the surface, the $\delta^{15} \mathrm{~N}$ of organic matter preserved within diatom frustules was measured at a number of depths within two of the sediment cores and compared to $\delta^{15} \mathrm{~N}_{\text {bulk }}$ (Figure 5).

[8] This comparison shows that the down core patterns of $\delta^{15} \mathrm{~N}$ in the diatom-bound organic $\mathrm{N}$ are very similar those of $\delta^{15} \mathrm{~N}_{\text {bulk }}$, with somewhat greater amplitude. The greater amplitude of diatom-bound $\delta^{15} \mathrm{~N}$ may reflect a contrast between the isotopic composition of the integrated community export and that of diatoms, which could arise from changes in community composition and/or trophic cycling [Galbraith, 2006; Montoya, 1994]. Alternatively, the amplitude of the $\delta^{15} \mathrm{~N}_{\text {bulk }}$ signal may have been muted relative to the $\delta^{15} \mathrm{~N}$ of exported organic matter by changes in the degradation of unprotected $\mathrm{N}$ over time, or because of the presence of an additional, relatively invariant $\mathrm{N}$ pool such as clay-bound N [Schubert and Calvert, 2001]. Regardless, the general agreement between diatom-bound and bulk $\mathrm{N}$ suggests that the imprint of diagenesis, although certainly present, is of secondary importance in generating down-core variability, such that the primary down core signal represents the $\delta^{15} \mathrm{~N}$ of organic matter exported from the surface above.

\subsection{Exported Organic Nitrogen}

[9] The $\delta^{15} \mathrm{~N}$ of exported organic matter can be viewed as a function of two independent factors. The first is the $\delta^{15} \mathrm{~N}$ of the nitrogen substrate that supported export, assumed to be represented by the nitrate immediately below the local euphotic zone, referred to here as $\delta^{15} \mathrm{~N}_{\text {nitrate. To first order, }}$ the $\delta^{15} \mathrm{~N}_{\text {nitrate }}$ is determined on a basin-wide or global scale by the relative inputs from $\mathrm{N}_{2}$ fixation, which adds $\delta^{15} \mathrm{~N}_{\text {nitrate }}$ of $\sim 0 \%$ [Liu et al., 1996], and the residual nitrate emanating from regions of water column denitrification, which is relatively enriched in ${ }^{15} \mathrm{~N}$ [Brandes and Devol, 2002; Cline and Kaplan, 1975; Deutsch et al., 2004]. The second factor is the degree to which the $\delta^{15} \mathrm{~N}$ of exported organic matter differs from that of $\delta^{15} \mathrm{~N}_{\text {nitrate. This }}$ has been shown to be controlled, to first order, by the annually integrated degree of relative nitrate utilization. 


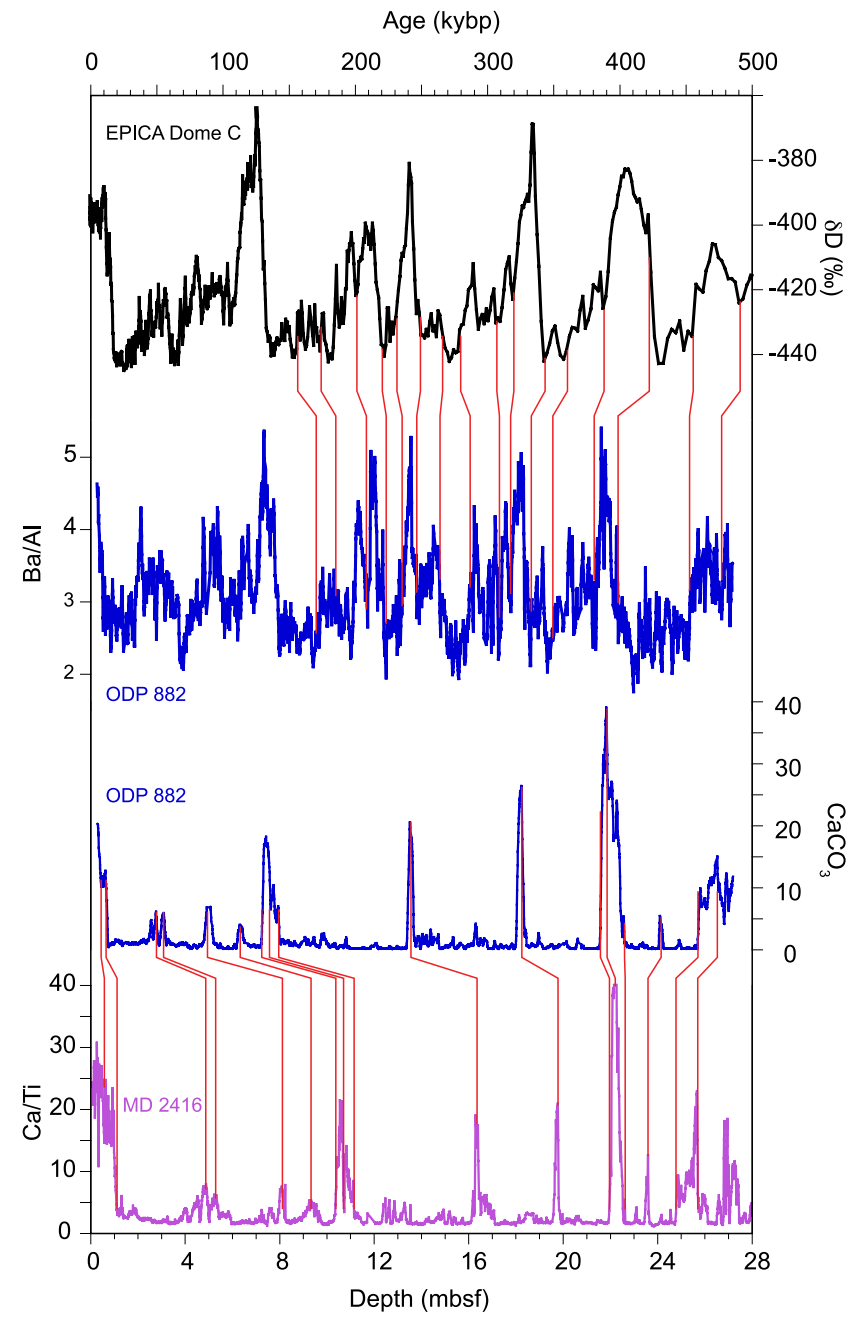

Figure 3. Chronostratigraphic ties for ODP 882 and MD2416. The EPICA Dome C (EDC) reference [EPICA Community Members, 2004] is shown by the black line (top) on the EDC2 timescale. The ODP $882 \mathrm{Ba} / \mathrm{Al}$ is shown by the blue line (second from top), with all new tie points (prior to $150 \mathrm{ka}$ ) shown by the red lines. The lower two curves show XRF-estimated $\mathrm{CaCO}_{3}$ and $\mathrm{Ca} / \mathrm{Ti}$ for ODP 882 and MD2416, respectively, with thin red lines showing the locations of all stratigraphic tie points.

Phytoplankton preferentially incorporate ${ }^{15} \mathrm{~N}$-depleted nitrate, so that the $\delta^{15} \mathrm{~N}$ of exported organic matter is lower than $\delta^{15} \mathrm{~N}_{\text {nitrate }}$ while nitrate utilization remains incomplete, approaching the $\delta^{15} \mathrm{~N}_{\text {nitrate }}$ as utilization nears completion [Altabet and Francois, 1994; Needoba et al., 2003; Sigman et al., 1999b]. In much of the global ocean nitrate consumption is essentially complete, so that the nitrate utilization signal disappears and the $\delta^{15} \mathrm{~N}$ of exported organic matter is equal to $\delta^{15} \mathrm{~N}_{\text {nitrate }}$ [Altabet et al., 1999; Thunell et al., 2004]. In most of the modern subarctic Pacific, however, nitrate consumption is perennially incomplete (Figure 1), so that the $\delta^{15} \mathrm{~N}$ of exported organic matter is lower than $\delta^{15} \mathrm{~N}_{\text {nitrate }}[$ Wu et al., 1999]. We note that incomplete nitrate consumption can also lead to spatial gradients of $\delta^{15} \mathrm{~N}_{\text {nitrate }}$ within a basin, since residual, high $\delta^{15} \mathrm{~N}$ nitrate tends to be advected away from nitraterich regions into the thermocline [Sigman et al., 2000]. However, given that such gradients seem to be relatively weak, we do not consider them further in the discussion that follows. Although it is frequently assumed that changes in only one of these two factors (either nitrate utilization or background $\delta^{15} \mathrm{~N}_{\text {nitrate }}$ ) dominates down core $\delta^{15} \mathrm{~N}$ variability at a given site, the possibility that both have varied strongly in the subarctic Pacific during the past $500 \mathrm{ka}$ demands a more nuanced analysis.

\section{Untangling the Isotopic Threads}

[10] Figure 6 presents our $\delta^{15} \mathrm{~N}_{\text {bulk }}$ results from the last glacial cycle for the three subarctic cores, as well as two previously published records from the North American margin, the locations of which are shown in Figure 1 [Hendy et al., 2004; Kienast et al., 2002]. Given that the $\delta^{15} \mathrm{~N}_{\text {bulk }}$ records appear to be recording changes in the $\delta^{15} \mathrm{~N}$ of organic matter exported from the subarctic Pacific surface, as argued above, we can now consider how the relative impacts of changes in $\delta^{15} \mathrm{~N}_{\text {nitrate }}$ and changes in nitrate utilization have contributed to our records.

[11] It has been argued that high $\delta^{15} \mathrm{~N}_{\text {nitrate }}$ produced by denitrification in the eastern tropical north Pacific oxygen minimum zone radiates outward, and that the magnitude of this influence has varied over time, as recorded in sedimentary $\delta^{15} \mathrm{~N}_{\text {bulk }}$ records on the North American margin [Kienast et al., 2002]. Despite the contrast in environments and great distance between the coastal sites of California and Oregon and the Gulf of Alaska site, the broad similarity in $\delta^{15} \mathrm{~N}_{\text {bulk }}$ testifies to a tight covariance of $\delta^{15} \mathrm{~N}_{\text {nitrate }}$ throughout the northeast and subarctic Pacific over the last

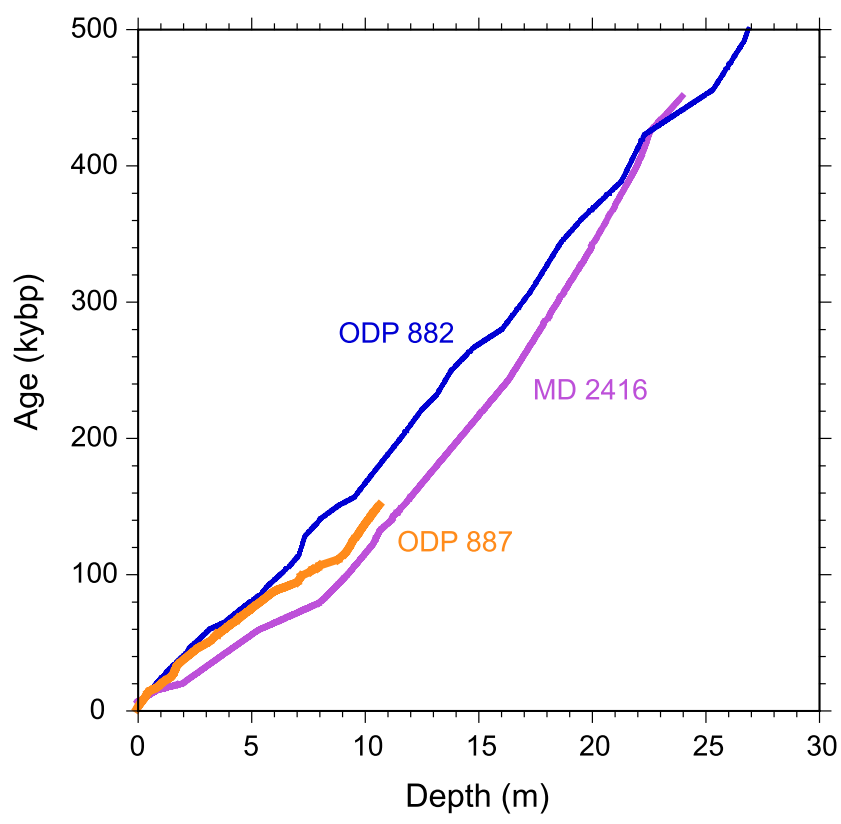

Figure 4. Age-depth relationships for the three sediment cores presented here. 

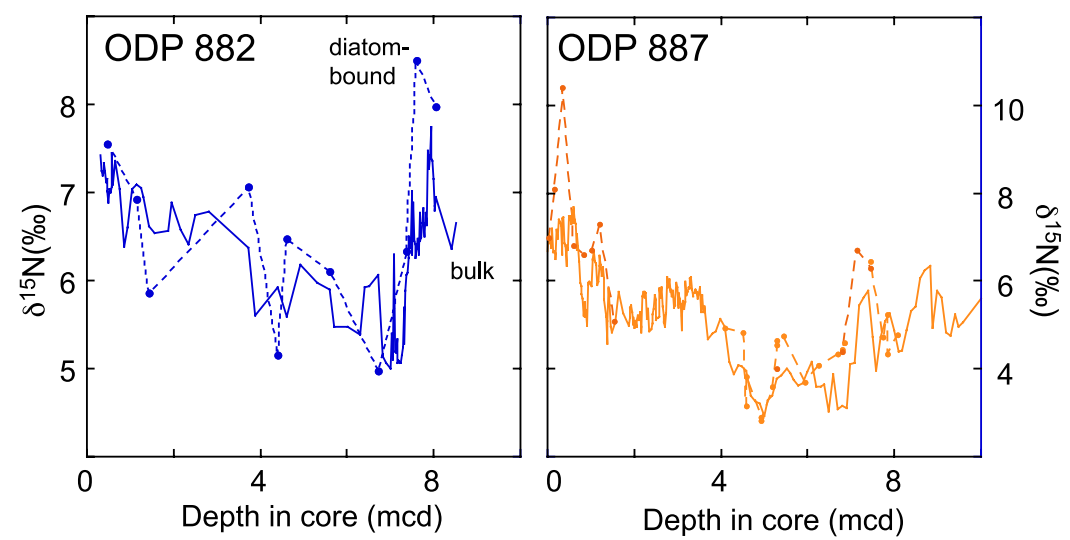

Figure 5. Comparison of the $\delta^{15} \mathrm{~N}$ of bulk sediments versus diatom-bound nitrogen at two deep water sites in the subarctic Pacific (see Figure 1 for locations). Bulk sedimentary $\delta^{15} \mathrm{~N}$ is shown by the solid lines, while diatom-bound measurements are shown by the solid symbols and dashed lines.

$60 \mathrm{ka}$. At the same time, it suggests that geographically independent variations in relative nitrate utilization at all three sites were minor over the last $60 \mathrm{ka}$, so that the regional $\delta^{15} \mathrm{~N}_{\text {nitrate }}$ variations emerged as the primary signal. It has been suggested that the dominant component of variability in all three eastern records was the relative contribution of residual high $\delta^{15} \mathrm{~N}$ nitrate from zones of water column denitrification, which has tended to be greater during globally warm periods [Galbraith et al., 2004; Ganeshram et al., 1995].

[12] The implication that relative nitrate utilization near the Gulf of Alaska site has been of only secondary importance in modulating $\delta^{15} \mathrm{~N}_{\text {bulk }}$ over this time period is somewhat surprising, given the nitrate-rich status of surface waters today and the pronounced sensitivity to iron addition experiments [Boyd et al., 2004]. The inferred small ampli-

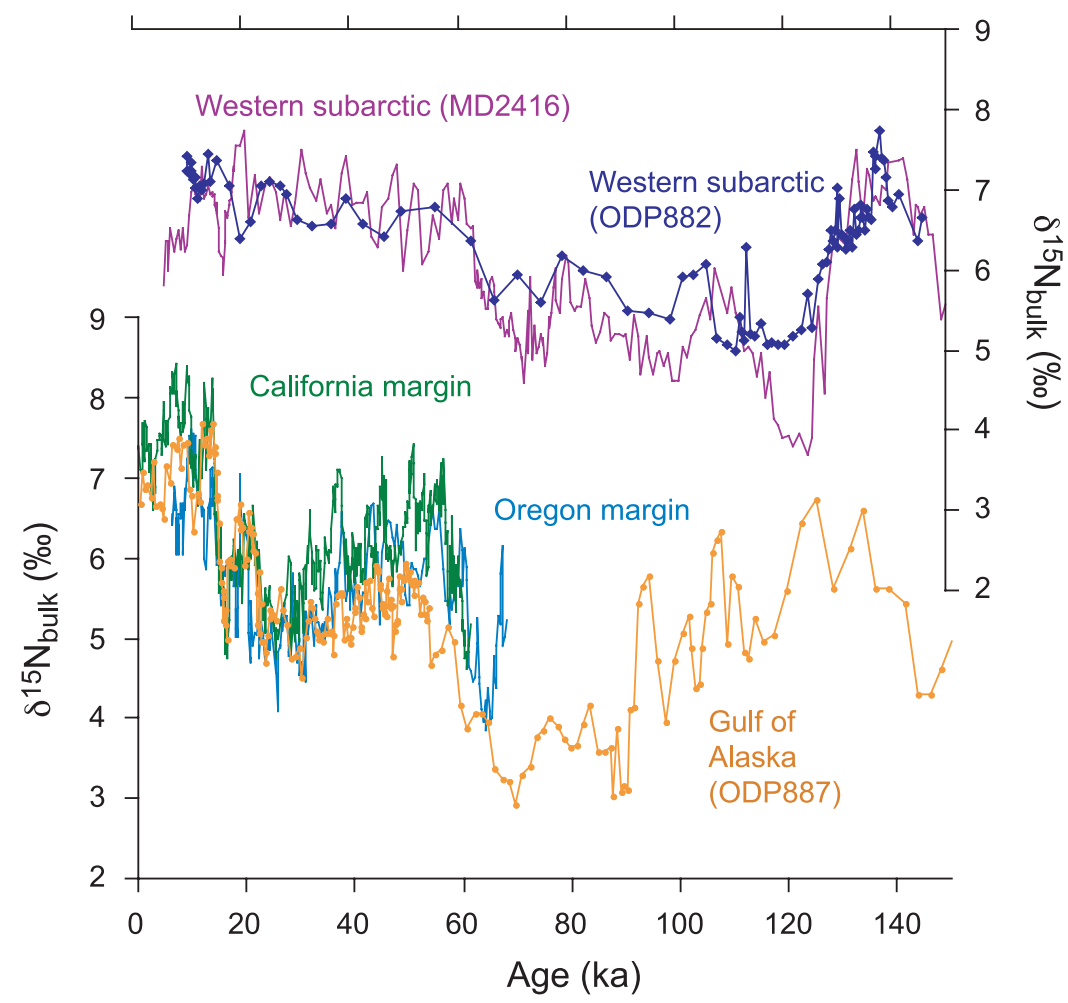

Figure 6. Bulk $\delta^{15} \mathrm{~N}$ records of the northeast and subarctic Pacific during the last glacial cycle. The California margin record is from ODP site 1017, as published by Hendy et al. [2004], while the Oregon record is the Midway site from the multicores transect, as published by Kienast et al. [2002]. 
tude of variations in relative nitrate utilization may indicate that the organic matter reaching the core site was derived largely from coastally influenced waters in which nitrate consumption was nearly complete throughout this period; alternatively, changes in organic nitrogen export and nitrate supply rates were strongly correlated, minimizing variations in relative nitrate utilization. Satellite observations of intense, coastally derived eddy activity in the vicinity of the core site [Ladd, 2007] and the identification of coastally sourced iron in the mixed layer of the central Gulf of Alaska [Lam et al., 2006] suggest that the lateral advected supply of iron from the continental shelf may continually support nitrate consumption here, intimately linking this site to the coast. We point out that during the 60-90 ka B.P. window, the Gulf of Alaska $\delta^{15} \mathrm{~N}_{\text {bulk }}$ is lower than that of coeval sediments on the North American margin, which suggests that relative nitrate utilization did vary at this site during earlier episodes.

[13] In contrast, the two western subarctic gyre records, which lie at the heart of the high nitrate low chlorophyll (HNLC) region, clearly show a different pattern of variability over the past $140 \mathrm{ka}$ (Figure 6). There, $\delta^{15} \mathrm{~N}_{\text {bulk }}$ decreased sharply between 120 and $130 \mathrm{ka}$ B.P., to reach a minimum near $110-120 \mathrm{ka}$ B.P., after which it gradually increased until reaching a relatively stable plateau that was maintained between $60 \mathrm{ka}$ B.P. and the core tops. That $\delta^{15} \mathrm{~N}_{\text {bulk }}$ in the two western cores is so similar, despite their being separated by a distance of $102 \mathrm{~km}$ and being raised from different water depths (2317 $\mathrm{m}$ and $3244 \mathrm{~m}$, Figure 1), indicates that this is a robust, regional pattern of $\delta^{15} \mathrm{~N}$ export variability. At present, $\delta^{15} \mathrm{~N}_{\text {nitrate profiles in the western }}$ subarctic Pacific are identical to those of the Gulf of Alaska within $<0.5 \%$ [Galbraith, 2006], consistent with rapid lateral exchange within the gyre [Ueno and Yasuda, 2003] that maintains regionally homogenous $\delta^{15} \mathrm{~N}_{\text {nitrate. Assuming }}$ that this pansubarctic isotopic homogeneity has reigned throughout the past $140 \mathrm{ka}$, the differences in $\delta^{15} \mathrm{~N}_{\text {bulk }}$ must be driven by changes in relative nitrate utilization at the western subarctic sites. This is not necessarily surprising, given that the western sites lie beneath waters that are currently more nitrate rich than the Gulf of Alaska (summer concentrations of 13 versus $7 \mu \mathrm{M}$ ), providing a greater potential magnitude of change than in the Gulf of Alaska, and are also closer to the east Asian source of aeolian iron [Duce and Tindale, 1991; Fan et al., 2006], which could have provided more time-variable iron fertilization of the surface waters. By this reasoning, the western $\delta^{15} \mathrm{~N}_{\text {bulk }}$ records, shown in their entirety at the top of Figure 4, should represent the sum of changes in the North Pacific $\delta^{15} \mathrm{~N}_{\text {nitrate }}$ plus changes in relative nitrate utilization.

[14] Given the superposition of these two signals, it would be advantageous to isolate that of relative nitrate utilization by removing the signal of $\delta^{15} \mathrm{~N}_{\text {nitrate }}$. Ideally, a "stack" of many North Pacific records of $\delta^{15} \mathrm{~N}_{\text {nitrate }}$ might be used to represent the regional background; however, there are very few available records that extend beyond the last glacial cycle, and a stacked record has yet to be constructed. Instead, we choose a single published record of sufficient length and temporal resolution, from the edge of the Eastern Tropical North Pacific (ETNP) shadow zone, the local source of ${ }^{15} \mathrm{~N}$-enriched nitrate to the North Pacific. Figure 4 shows part of the long $\delta^{15} \mathrm{~N}_{\text {bulk }}$ record from ODP site 1012 on the Californian/Mexican borderlands, recently published by Liu et al. [2005] using a benthic $\delta^{18} \mathrm{O}$ stratigraphy and interpreted as a record of local $\delta^{15} \mathrm{~N}_{\text {nitrate. }}$. The proximity of ODP site 1012 to the ETNP oxygen minimum zone (OMZ), in which denitrification preferentially removes ${ }^{14} \mathrm{~N}$, causes the local $\delta^{15} \mathrm{~N}_{\text {nitrate }}$ to be elevated relative to sites further north [Altabet et al., 1999; Sigman et al., 2003], so that the core top $\delta^{15} \mathrm{~N}_{\text {bulk }}$ is currently $8-9 \%$ [Liu et al., 2005], higher than observed on the margins of central California and Oregon (Figure 7). The more direct input of OMZ water to the borderlands site should cause the amplitude of past OMZ-derived variability to be substantially greater than in the subarctic Pacific. This could be seen as a boon, since the greater amplitude should have helped OMZ-derived changes in $\delta^{15} \mathrm{~N}_{\text {nitrate }}$ to rise above any background noise, ensuring that they will have dominated this record. Following the reasoning outlined above, subtraction of the borderlands $\delta^{15} \mathrm{~N}_{\text {nitrate }}$ record from the $\delta^{15} \mathrm{~N}_{\text {bulk }}$ of the two western subarctic sites should leave a residual signal that is dominated by changes in relative nitrate utilization.

[15] In order to calculate the differences, each of the three records was linearly interpolated to $1 \mathrm{ka}$ intervals, the mean was removed, and the result smoothed using a 9 ka running average, in order to subdue short-term $\delta^{15} \mathrm{~N}_{\text {bulk }}$ fluctuations with periods less than the chronological uncertainty. Given that the borderlands site lies very close to the ETNP source of isotopic variability, its OMZ-related $\delta^{15} \mathrm{~N}_{\text {nitrate }}$ variability has a larger amplitude than other parts of the Pacific [Galbraith et al., 2004; Kienast, 2000], so that dilution of ETNP waters should have dampened the amplitude of changes in the subarctic Pacific. Therefore, the normalized ODP site 1012 record should be multiplied by a "dilution" coefficient $d<1$ prior to subtraction, in order to obtain an amplitude more representative of the expected subarctic variability. Unfortunately, there is no obvious way in which $d$ can be estimated from first principles, since it depends on the relative contribution of $\mathrm{OMZ}$ waters to the subarctic Pacific. Indeed, the dilution may have varied over time according to the physical circulation, as suggested by Kienast et al. [2002], though given the lack of information we currently assume that it was constant. We therefore take a conservative value of $d=0.6$, so that the most extreme deviation from the core top value in ODP1012, -2.5\%o, produces an inferred OMZ-driven change of $-1.5 \%$ in the subarctic Pacific. Our results are relatively insensitive to the precise value of $d$, as they are to minor errors in the age models, as shown in Figure 8. The interpretation given below assumes that temporal variations of $d$ are minor.

\section{Implications}

[16] The western subarctic Pacific $\delta^{15} \mathrm{~N}_{\text {bulk }}$ difference curves, shown in Figure 9, show a qualitatively different form than either the ODP 1012 or ODP882/MD2416 $\delta^{15} \mathrm{~N}_{\text {bulk }}$ records. The most straightforward interpretation for this is that an extremely consistent relationship has held between global climate and nitrate utilization in western 


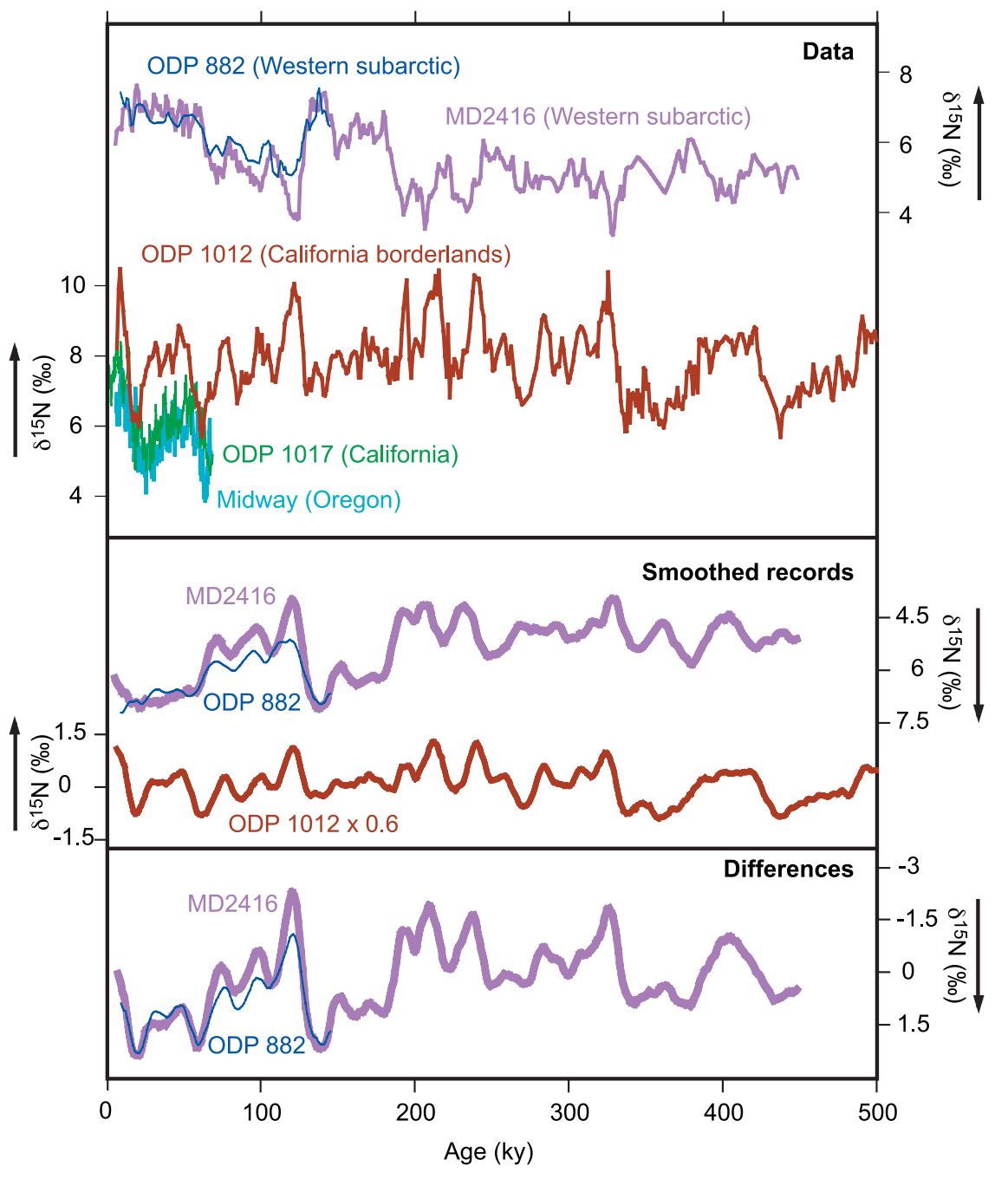

Figure 7. Removal of the North Pacific $\delta^{15} \mathrm{~N}_{\text {nitrate }}$ component from western subarctic Pacific $\delta^{15} \mathrm{~N}_{\text {bulk }}$ records. (top) The measured $\delta^{15} \mathrm{~N}_{\text {bulk }}$ records of MD2416 and ODP882, as well as the $\delta^{15} \mathrm{~N}_{\text {bulk }}$ of ODP1012 from the California borderlands [Liu et al., 2005]. (middle) The smoothed, interpolated records, with the ODP1012 record multiplied by $a=0.6$ as described in the text. (bottom) The differences between the western subarctic sites and ODP1012, which, as argued in the text, provide the $\delta^{15} \mathrm{~N}$ changes attributed to nitrate utilization in the subarctic surface.

subarctic Pacific surface waters over the past four and a half glacial cycles. The consistency of this relationship can be quantified, very roughly, by the correlation with the benthic $\delta^{18} \mathrm{O}$ stack also shown in Figure 9. For the original $\delta^{15} \mathrm{~N}$ records, correlation coefficients $\left(r^{2}\right)$ calculated with the benthic $\delta^{18} \mathrm{O}$ stack were 0.33 for both MD2416 and ODP1012, while for the difference curve the $r^{2}$ is 0.65 . This relationship implies that lower deep water temperatures and greater ice sheet volume are generally associated with increased relative utilization of nitrate in the western subarctic Pacific, and that as global benthic $\delta^{18} \mathrm{O}$ decreases the relative nitrate utilization decreases in a regular and predictable way. The apparent magnitude of the change depends on the details of the difference calculation (Figure 5), but is generally $\sim 2.5-3 \%$ o per glacial cycle.

[17] This amplitude of glacial-interglacial change can be interpreted semiquantitatively by comparison to the present- day relative nitrate utilization. Assuming Rayleigh distillation kinetics, the integrated organic nitrogen export has an isotopic composition given by

$$
\delta^{15} \mathrm{~N}_{\text {export }}=\delta^{15} \mathrm{~N}_{\text {nitrate }}+\varepsilon f \ln (f) /(1-f)
$$

where $\varepsilon$ is the isotope effect for nitrate incorporation by phytoplankton and $f$ is the fraction of nitrate unutilized on a seasonal basis [Altabet and Francois, 1994; Mariotti et al., 1981]. Although $\varepsilon$ can vary between species and under different growth conditions [Needoba et al., 2003], we make the simplifying assumption here that the effective community isotope effect is invariant. The difference in climatological surface nitrate concentrations between January-March and July-September [Conkright et al., 2002], averaged over the region $166-169^{\circ} \mathrm{E}$ and $50-52^{\circ} \mathrm{N}$, 


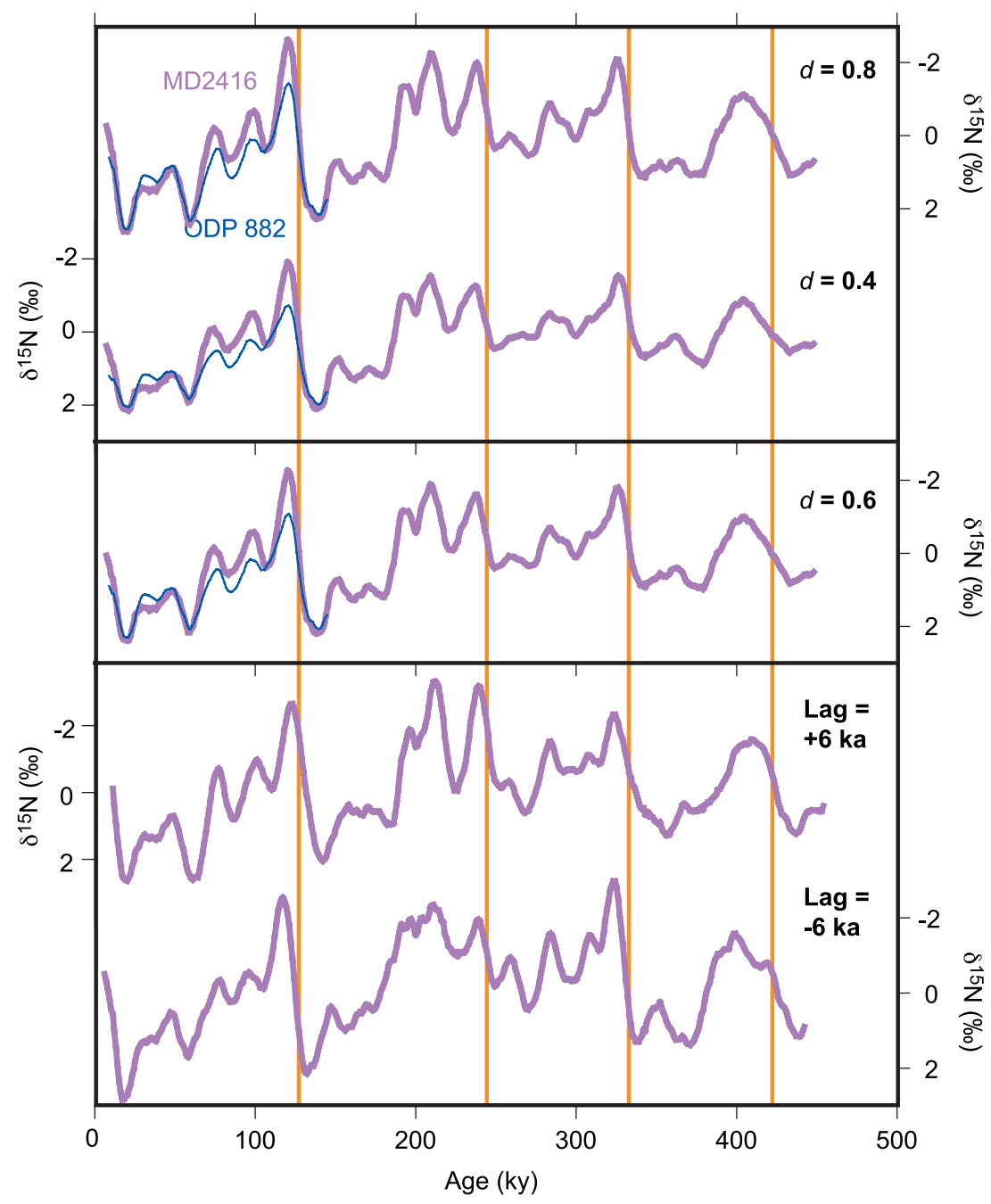

Figure 8. Sensitivities of the difference record to uncertainties in $d$ and age model. (middle) The difference record generated with the standard age model and $d=0.6$, as also shown in Figures 4 and 6. (top) The difference curves generated with alternate values of $d$ (i.e., the fraction of $\delta^{15} \mathrm{~N}_{\text {nitrate }}$ variability recorded in ODP 1012 expected to appear in subarctic Pacific $\delta^{15} \mathrm{~N}_{\text {nitrate }}$ ). (bottom) The difference curves generated by lagging the MD2416 age model uniformly by both +6 and $-6 \mathrm{ka}$, while the age model for ODP1012 was not varied (note $d=0.6$ in both these cases).

gives a modern day $f$ of 0.53 . Therefore, given an $\varepsilon$ of $5 \%$ [Brunelle et al., 2007], modern $\delta^{15} \mathrm{~N}_{\text {export }}$ would be expected to be $3.5 \%$ lower than $\delta^{15} \mathrm{~N}_{\text {nitrate. This value is of }}$ only slightly greater magnitude than the range of glacialinterglacial change observed in our record of relative nitrate utilization (Figure 9), the amplitude of which may well be underestimated if the variability in $\delta^{15} \mathrm{~N}_{\text {bulk }}$ is indeed muted, as suggested by the diatom $\delta^{15} \mathrm{~N}$. Thus, during full glacial maxima, the consumption of nitrate at the surface of the western subarctic Pacific approached completion in summer, so that it was not the pronounced HNLC region that it is today.

[18] Conceptually, relative nitrate consumption could be increased by two mechanisms: (1) by inhibiting nitrate resupply to the euphotic zone and (2) by increasing the capability of the surface ecosystem to strip nitrate out of the mixed layer through the export of organic nitrogen. The concentrations of biogenic opal and nonlithogenic $\mathrm{Ba}(\mathrm{Ba}-\mathrm{xs})$ in subarctic Pacific sediments are both strongly reduced during glacial stages (e.g., Figure 9), which has been taken as evidence for reduced export production during cold climate periods [Brunelle et al., 2007; Jaccard et al., 2005; Kienast et al., 2004; Narita et al., 2002; Shigemitsu et al., 2007]. Although it has been suggested that the episodes of peak export production occurred during glacial terminations, rather than during interglacials [Crusius et al., 2004; Sarnthein et al., 2006] we assume, for the purposes of this discussion, that the interpretation of lower export production during glacial periods is correct to first order.

[19] General hypotheses of polar ocean stratification [Brunelle et al., 2007; Francois et al., 1997; Jaccard et al., 2005; Sigman et al., 2004] call on enhanced vertical stability of the high-latitude water column to simultaneously explain reduced export and increased nitrate consumption 


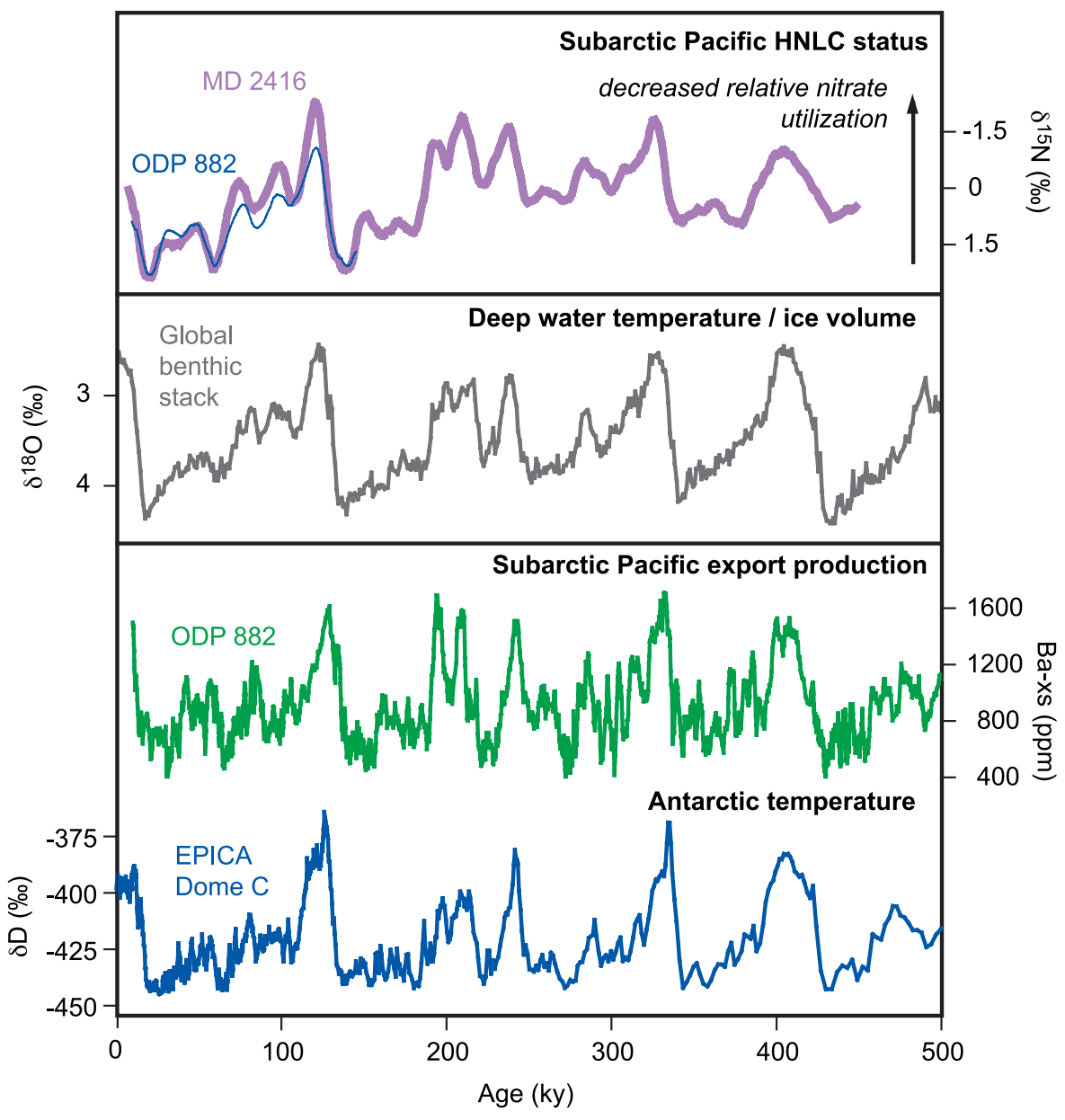

Figure 9. Subarctic Pacific relative nitrate utilization in the context of local export production and global climate. (top) The difference records, as also shown in Figure 4. The gray line is the global benthic $\delta^{18} \mathrm{O}$ stack of Lisiecki and Raymo [2005], which reflects a combination of globally averaged bottom water temperature and ice sheet volume. The Ba-xs is as published by Jaccard et al. [2005]. The Antarctic Dome C temperature record is from EPICA Community Members [2004].

during the glacial periods, an appeal to the reduced nitrate resupply mechanism. Such a reduction in nitrate supply to the subarctic Pacific surface might have been caused by purely local changes in the physical circulation, such as a change in the pycnocline driven by changes in the freshwater and heat balance. It has, however, been argued that the subarctic Pacific pycnocline actually strengthened through the Holocene [Sarnthein et al., 2004] which, if true, might indicate another explanation. A second possible local circulation change would have been an enhanced exchange between the subarctic and subtropical gyres, so that more nutrient-poor subtropical water was drawn north, thereby reducing surface nutrient concentrations, analogous to the modern subarctic Atlantic. Resolving the relative contributions of such local mechanisms will require detailed proxy reconstructions of the physical circulation history of the North Pacific. Alternatively, a more fundamental change in global ocean circulation could have modulated the subarctic Pacific HNLC remotely, by controlling the distri- bution of nutrients between the deep ocean and the sunlit surface [e.g., Boyle, 1988; Schmittner, 2005].

[20] Glacial iron fertilization could, in contrast, have immediately induced the second mechanism by increasing the rate at which phytoplankton were able to export available macronutrients from the subarctic Pacific surface itself. The evidence for reduced export production during the glacial period would seem, at first, to obviate the possibility that iron fertilization caused enhanced glacial nitrate utilization, as discussed by Kienast et al. [2004]. However, iron fertilization at a global scale would most likely have modulated the spatial distribution of export production and remineralization, which would, in turn, have redistributed the nutrient wealth of the ocean, subject to the physical circulation. Such speculative mechanisms could be explored in a numerical model.

[21] Unfortunately, the data currently available do not provide a clear resolution to the relative importance of changes in physical circulation versus changes in micronutrient nutrition. Indeed, the tandem evidence for both 
enhanced glacial dust fluxes [Petit et al., 1999; Ruth et al., 2003] and marked changes in the physical circulation [de Boer et al., 2007; Matsumoto et al., 2002; Sarnthein et al., 2007; Sigman et al., 2004] would suggest that both mechanisms played some role in increasing relative nitrate utilization. At the same time, however, the strength of the correlation between nitrate utilization and global climate apparent in Figure 9 does appeal, on aesthetic grounds, to a relatively simple causal relationship. In addition, the fact that $\delta^{15} \mathrm{~N}$ records from the Southern Ocean indicate greater nitrate consumption during the glacial maximum [Francois et al., 1997; Robinson et al., 2004; Robinson et al., 2005; Sigman et al., 1999a], in parallel to the trend observed here, hints that a common physical relationship modulated the nutrient budget of both these polar regions. We note, regardless, that both mechanisms involve a decrease in the rate at which $\mathrm{CO}_{2}$ would have leaked from the subarctic Pacific surface, increasing the effectiveness of the biological pump in sequestering respired carbon in the ocean interior and thereby contributing toward the low glacial atmospheric $\mathrm{pCO}_{2}$ [Sigman and Haug, 2003].

[22] Acknowledgments. We are grateful to Michael Sarnthein for many spirited and stimulating discussions; our initially divergent interpretations were largely reconciled through extensive correspondence, insofar as the available data allowed clear conclusions to be reached. Sediment cores were collected and made available through the IMAGES and ODP programs, with samples from MD2416 provided by M. Sarnthein. Kathy Gordon and Maureen Soon provided much appreciated technical assistance, while the Natural Science and Engineering Research Council of Canada, the Canadian Institute For Advanced Research, and the Swiss National Science Foundation provided funding. Additional financial support for diatom-bound $\mathrm{N}$ measurements was provided by NSF grants OCE0136449 and ANT-0453680, by BP and Ford Motor Company through the Princeton Carbon Mitigation Initiative, and by a NDSEG fellowship to B.G.B. Steve Calvert, Roger Francois, and Lou Codispoti made thoughtful contributions on an early, dissertation format progenitor of this paper. We thank Robert Thunell and one anonymous reviewer for insightful and constructive comments.

\section{References}

Altabet, M. A., and R. Francois (1994), Sedimentary nitrogen isotopic ratio as a recorder for surface ocean nitrate utilization, Global Biogeochem. Cycles, 8, 103-116, doi:10.1029/93GB03396.

Altabet, M. A., C. Pilskaln, R. Thunell, C. Pride, D. Sigman, F. Chavez, and R. Francois (1999), The nitrogen isotope biogeochemistry of sinking particles from the margin of the eastern North Pacific, Deep-Sea Res. I, 46(4), 655679, doi:10.1016/S0967-0637(98)00084-3.

Boyd, P. W., et al. (2004), The decline and fate of an iron-induced subarctic phytoplankton bloom, Nature, 428(6982), 549-553, doi:10.1038/nature02437.

Boyle, E. A. (1988), Vertical oceanic nutrient fractionation and glacial interglacial $\mathrm{CO}^{2}$ cycles, Nature, 331(6151), 55-56, doi:10.1038/ $331055 \mathrm{a} 0$

Brandes, J. A., and A. H. Devol (2002), A global marine-fixed nitrogen isotopic budget: Implications for Holocene nitrogen cycling, Global Biogeochem. Cycles, 16(4), 1120, doi:10.1029/ $2001 \mathrm{~GB} 001856$.

Brunelle, B. G., D. M. Sigman, M. S. Cook, L. D. Keigwin, G. H. Haug, B. Plessen, G. Schettler, and S. L. Jaccard (2007), Evidence from diatom-bound nitrogen isotopes for subarctic Pacific stratification during the last ice age and a link to North Pacific denitrification changes, Paleoceanography, 22, PA1215, doi:10.1029/2005PA001205.

Cline, J. D., and I. R. Kaplan (1975), Isotopic fractionation of dissolved nitrate during denitrification in the eastern tropical north Pacific Ocean, Mar. Chem., 3, 271-299, doi:10.1016/ 0304-4203(75)90009-2.

Conkright, M. E., R. A. Locarnini, H. E. Garcia, T. D. O'Brien, T. P. Boyer, C. Stephens, and J. I. Antonov (2002), World Ocean Atlas 2001: Objective Analyses, Data Statistics and Figures [CD-ROM], Natl. Oceanogr. Data Cent., Silver Spring, Md.

Crusius, J., T. F. Pedersen, S. Kienast, L. Keigwin, and L. Labeyrie (2004), Influence of northwest Pacific productivity on North Pacific intermediate water oxygen concentrations during the Bølling-Allerod interval (14.7$12.9 \mathrm{ka})$, Geology, 32(7), 633-636, doi:10.1130/G20508.1. de Boer, A. M., D. M. Sigman, J. R. Toggweiler, and J. L. Russell (2007), Effect of global ocean temperature change on deep ocean ventilation, Paleoceanography, 22, PA2210, doi:10.1029/ 2005PA001242.

Deutsch, C., D. M. Sigman, R. C. Thunell, A. N. Meckler, and G. H. Haug (2004) Isotopic constraints on glacial/interglacial changes in the oceanic nitrogen budget, Global Biogeochem. Cycles, 18, GB4012, doi:10.1029/ 2003GB002189.

Duce, R. A., and N. W. Tindale(1991), Atmospheric Transport of Iron and Its Deposition in the Ocean, Limnol. Oceanogr., 36(8), 1715-1726.

EPICA Community Members (2004), Eight glacial cycles from an Antarctic ice core, Nature, 429, 623-628, doi:10.1038/nature02599.

Fan, S.-M., W. J. Moxim, and H. Levy II (2006), Aeolian input of bioavailable iron to the ocean, Geophys. Res. Lett., 33, L07602, doi:10.1029/ 2005 GL024852.

Francois, R., M. A. Altabet, E-.F. Yu, D. M. Sigman, M.P. Bacon, M. Frank, G. Bohrmann, G. Bareille, and L. D. Labeyrie (1997), Contribution of Southern Ocean surface-water stratification to low atmospheric $\mathrm{CO}_{2}$ concentrations during the last glacial period, Nature, 389(6654), 929-935, doi:10.1038/40073.

Galbraith, E. D. (2006), Interactions between climate and the marine nitrogen cycle on glacialinterglacial timescales, Ph.D. thesis, $228 \mathrm{pp}$. Univ. of B. C., Vancouver.

Galbraith, E. D., M. Kienast, T. F. Pedersen, and S. E. Calvert (2004), Glacial-interglacia modulation of the marine nitrogen cycle by high-latitude $\mathrm{O}_{2}$ supply to the global thermocline, Paleoceanography, 19, PA4007, doi:10.1029/2003PA001000

Galbraith, E. D., S. L. Jaccard, T. F. Pedersen, D. M. Sigman, G. H. Haug, M. Cook, J. R. Southon, and R. Francois (2007), Carbon dioxide release from the North Pacific abyss during the last deglaciation, Nature, 449(7164), 890-893, doi:10.1038/nature06227.

Ganeshram, R. S., T. F. Pedersen, S. E. Calvert, and J. W. Murray (1995), Large changes in oceanic nutrient inventories from glacial to interglacial periods, Nature, 376, 755-758, doi:10.1038/376755a0
Ganeshram, R. S., T. F. Pedersen, S. E. Calvert G. W. McNeill, and M. R. Fontugne (2000), Glacial-interglacial variability in denitrification in the world's oceans: Causes and consequences, Paleoceanography, 15(4), 361-376, doi:10.1029/1999PA000422.

Haug, G. H., D. M. Sigman, R. Tiedemann, T. F. Pedersen, and M. Sarnthein (1999), Onset of permanent stratification in the subarctic Pacific Ocean, Nature, 401(6755), 779-782, doi:10.1038/44550.

Hendy, I. L., T. F. Pedersen, J. P. Kennett, and R. Tada (2004), Intermittent existence of a southern Californian upwelling cell during submillennial climate change of the last $60 \mathrm{kyr}$ Paleoceanography, 19, PA3007, doi:10.1029/ 2003PA000965.

Jaccard, S. L., G. H. Haug, D. M. Sigman, T. F. Pedersen, H. R. Thierstein, and U. Röhl (2005), Glacial/interglacial changes in subarctic North Pacific stratification, Science, 308(5724), 1003-1006, doi:10.1126 science. 1108696

Kiefer, T., M. Sarnthein, H. Erlenkeuser, P. M Grootes, and A. P. Roberts (2001), North Pacific response to millenial-scale changes in ocean circulation over the last $60 \mathrm{kyr}$, Paleoceanography, 16, 179-189, doi:10.1029/ 2000PA000545.

Kienast, M. (2000), Unchanged nitrogen isotopic composition of organic matter in the South China Sea during the last climatic cycle: Global implications, Paleoceanography, 15(2), 244-253, doi:10.1029/1999PA000407.

Kienast, S. S., S. E. Calvert, and T. F. Pedersen (2002), Nitrogen isotope and productivity variations along the northeast Pacific margin over the last $120 \mathrm{kyr}$ : Surface and subsurface paleoceanography, Paleoceanography, 17(4), 1055, doi:10.1029/2001PA000650

Kienast, S. S., I. L. Hendy, J. Crusius, T. F Peoersen, and S. E. Calvert (2004), Export production in the subarctic North Pacific over the last 800 kyrs: No evidence for iron fertilization?, J. Oceanogr., 60(1), 189-203, doi:10.1023/B:JOCE.0000038326.73943.aa.

Ladd, C. (2007), Interannual variability of the Gulf of Alaska eddy field, Geophys. Res. Lett. 34, L11605, doi:10.1029/2007GL029478. 
Lam, P. J., J. K. B. Bishop, C. C. Henning, M. A. Marcus, G. A. Waychunas, and I. Y. Fung (2006), Wintertime phytoplankton bloom in the subarctic Pacific supported by continental margin iron, Global Biogeochem. Cycles, 20, GB1006, doi:10.1029/2005GB002557.

Lisiecki, L.E., and M. E. Raymo(2005), A PliocenePleistocene stack of 57 globally distributed benthic $\delta^{18} \mathrm{O}$ records, Paleoceanography, 20, PA1003, doi:10.1029/2004PA001071.

Liu, K.-K., M.-J. Su, C.-R. Hsueh, and G.-C. Gong (1996), The nitrogen isotopic composition of nitrate in the Kuroshio Water northeast of Taiwan: Evidence for nitrogen fixation as a source of isotopically light nitrate, Mar. Chem., $54(3), 273-292$, doi:10.1016/03044203(96)00034-5.

Liu, Z., M. A. Altabet, and T. D. Herbert (2005), Glacial-interglacial modulation of eastern tropical North Pacific denitrification over the last 1.8-Myr, Geophys. Res. Lett., 32, L23607, doi:10.1029/2005GL024439.

Mariotti, A., C. Germon, P. Hubert, P. Kaiser, R. Letolle, A. Tardieux, and P. Tardieux (1981), Experimental determination of nitrogen kinetic isotope fractionation: Some principles; Illustration for the Denitrification and Nitrification Processes, Plant Soil, 62(3), 413-430, doi:10.1007/BF02374138.

Martin, J. H. (1990), Glacial-interglacial $\mathrm{CO}_{2}$ change: The iron hypothesis, Paleoceanography, 5, 1-13, doi:10.1029/PA005i001p00001.

Matsumoto, K., T. Oba, J. Lynch-Stieglitz, and H. Yamamoto (2002), Interior hydrography and circulation of the glacial Pacific Ocean, Quat. Sci. Rev., 21(14-15), 1693-1704, doi:10.1016/S0277-3791(01)00142-1.

McDonald, D. (1997), The late Quaternary history of primary productivity in the subarctic east Pacific, M. S. thesis, 201 pp., Univ. of B. C., Vancouver

Montoya, J. P. (1994), Nitrogen isotope fractionation in the modern ocean: Implications for the sedimentary record, in Carbon Cycling in the Glacial Ocean: Constraints on the Ocean's Role in Global Change, edited by R. Zahn, T. F. Pedersen, and M. A. Kaminski, pp. 259-279, Springer-Verlag, New York.

Narita, H., M. Sato, S. Tsunogai, M. Murayama, M. Ikehara, T. Nakatsuka, M. Wakatsuchi, N. Harada, and Y. Ujiié (2002), Biogenic opal indicating less productive northwestern North Pacific during the glacial ages, Geophys. Res. Lett., 29(15), 1732, doi:10.1029/ 2001GL014320.

Needoba, J. A., N. A. Waser, P. J. Harrison, and S. E. Calvert (2003), Nitrogen isotope fractionation in 12 species of marine phytoplankton during growth on nitrate, Mar. Ecol. Prog. Ser., 255, 81-91, doi:10.3354/meps255081.

Nürnberg, D., and R. Tiedemann (2004), Environmental change in the Sea of Okhotsk during the last 1.1 million years, Paleoceanography, 19, PA4011, doi:10.1029/2004PA001023.

Petit, J. R., et al. (1999), Climate and atmospheric history of the past 420,000 years from the Vostok ice core, Antarctica, Nature, 399(6735), 429-436, doi:10.1038/20859.

Robinson, R. S., B. G. Brunelle, and D. M. Sigman (2004), Revisiting nutrient utilization in the glacial Antarctic: Evidence from a new method for diatom-bound $\mathrm{N}$ isotopic analysis, Paleoceanography, 19, PA3001, doi:10.1029/ 2003PA000996.

Robinson, R. S., D. M. Sigman, P. J. DiFiore, M. M. Rohde, T. A. Mashiotta, and D. W. Lea (2005), Diatom-bound ${ }^{15} \mathrm{~N} /{ }^{14} \mathrm{~N}$ : New support for enhanced nutrient consumption in the ice age subantarctic, Paleoceanography, 20, PA3003, doi:10.1029/2004PA001114.

Ruth, U., D. Wagenbach, J. P. Steffensen, and M. Bigler (2003), Continuous record of microparticle concentration and size distribution in the central Greenland NGRIP ice core during the last glacial period, J. Geophys. Res., 108(D3), 4098, doi:10.1029/2002JD002376.

Sancetta, C., and S. Silvestri (1984), Diatom stratigraphy of the late Pleistocene (Brunhes) ubarctic Pacific, Mar. Micropaleontol., 9, 263-274, doi:10.1016/0377-8398(84)90016-1.

Sarnthein, M., H. Gebhardt, T. Kiefer, M. Kucera, M. Cook, and H. Erlenkeuser (2004), MidHolocene origin of the sea-surface salinity low in the subarctic North Pacific, Quaternary, Sci. Rev. (Singap.), 23, 2089-2099, doi:10.1016 j.quascirev.2004.08.008.

Sarnthein, M., H. Gebhardt, T. Kiefer, H. Erlenkeuser, C. Kissel, and F. Schmieder (2005), 95-ky cycles of ocean circulation in the far northwestern Pacific and South China Sea during the Brunhes Chron, paper presented at Milutin Milankovitch Anniversary Symposium: Paleoclimate and the Earth Climate System, Serbian Acad. of Sci. and Arts, Belgrade.

Sarnthein, M., T. Kiefer,P. M. Grootes, H. Elderfield, and H. Erlenkeuser (2006), Warmings in the far northwestern Pacific promoted pre-Clovis immigration to America during Heinrich event 1, Geology, 34(3), 141-144, doi:10.1130/ G22200.1.

Sarnthein, M., P. M. Grootes, J. P. Kennett, and M.-J. Nadeau (2007), ${ }^{14} \mathrm{C}$ reservoir ages show deglacial changes in ocean currents and carbon cycle, in Ocean Circulation: Mechanisms and Impacts-Past and Future Changes of the Oceanic Meridional Overturning Circulation: Mechanisms and Impacts, Geophys. Monogr Ser, vol. 173, edited by A. Schmittner, J. C. H. Chiang, and S. R. Hemming, pp. 175-196, AGU, Washington, D. C.

Schmittner, A. (2005), Decline of the marine ecosystem caused by a reduction in the Atlantic overturning circulation, Nature, 434(7033), 628-633, doi:10.1038/nature03476.

Schubert, C. J., and S. E. Calvert (2001), Nitrogen and carbon isotopic composition of marine and terrestrial organic matter in Arctic Ocean sediments: implications for nutrient utilization and organic matter composition, Deep-Sea Res. I, 48(3), 789-810, doi:10.1016/S09670637(00)00069-8.

Shigemitsu, M., H. Narita, Y. W. Watanabe, N. Harada, and S. Tsunogai (2007), Ba, Si, U, $\mathrm{Al}$, Sc, $\mathrm{La}, \mathrm{Th}, \mathrm{C}$ and ${ }^{13} \mathrm{C} /{ }^{12} \mathrm{C}$ in a sediment core in the western subarctic Pacific as proxies of past biological production, Mar. Chem., 106, 442455, doi:10.1016/j.marchem.2007.04.004.

Sigman, D. M., and G. H. Haug (2003), The biological pump in the past, in Treatise on Geochemistry, edited by D. Holland and K. K. Turekian, pp. 491-528, Elsevier, Amsterdam.
Sigman, D. M., M. A. Altabet, R. Francois, D. C. McCorkle, and J.-F. Gaillard (1999a), The isotopic composition of diatom-bound nitrogen in Southern Ocean sediments, Paleoceanography, 14(2), 118-134, doi:10.1029/ 1998PA900018.

Sigman, D. M., M. A. Altabet, D. C. McCorkle, R. Francois, and G. Fischer (1999b), The $\delta^{15} \mathrm{~N}$ of nitrate in the Southern Ocean: Consumption of nitrate in surface waters, Global Biogeochem. Cycles, 13(4), 11491166, doi:10.1029/1999GB900038.

Sigman, D. M., et al. (2000), The $\delta^{15} \mathrm{~N}$ of nitrate in the Southern Ocean: Nitrogen cycling and circulation in the ocean's interior, J. Geophys. Res., 105(C8), 19,599-19,614.

Sigman, D. M., R. Robinson, A. N. Knapp, A. van Geen, D. C. McCorkle, J. A. Brandes, and R. C. Thunell (2003), Distinguishing between water column and sedimentary denitrification in the Santa Barbara Basin using the stable isotopes of nitrate, Geochem. Geophys. Geosyst., 4(5), 1040, doi:10.1029/2002GC000384.

Sigman, D. M., S. L. Jaccard, and G. H. Haug (2004), Polar ocean stratification in a cold climate, Nature, 428(6978), 59-63, doi:10.1038/nature02357.

Thunell, R. C., D. M. Sigman, F. Muller-Karger, Y. Astor, and R. Varela (2004), Nitrogen isotope dynamics of the Cariaco Basin, Venezuela, Global Biogeochem. Cycles, 18 , GB3001, doi:10.1029/2003GB002185.

Ueno, H., and I. Yasuda (2003), Intermediate water circulation in the North Pacific subarctic and northern subtropical regions, J. Geophys. Res., 108(C11), 3348, doi:10.1029/ 2002JC001372.

Whitney, F. A., W. R. Crawford, and P. J. Harrison (2005), Physical processes that enhance nutrient transport and primary productivity in the coastal and open ocean of the subarctic NE Pacific, Deep-Sea Res. II, 52(5-6), 681706, doi:10.1016/j.dsr2.2004.12.023.

Wu, J. P., S. E. Calvert, C. S. Wong, and F. A. Whitney (1999), Carbon and nitrogen isotopic composition of sedimenting particulate material at Station Papa in the subarctic northeast Pacific, Deep-Sea Res. II, 46(11), 2793 2832, doi:10.1016/S0967-0645(99)00084-3.

B. G. Brunelle, E. D. Galbraith, and D. M. Sigman, Department of Geosciences, Princeton University, Guyot Hall, Washington Road, Princeton, NJ 08544, USA. (egalbrai@princeton.edu)

S. L. Jaccard, Geological Institute, Department of Earth Sciences, Eidgenossische Technische Hochschule Zurich, Rämistrasse 101, CH-8092 Zurich, Switzerland.

T. Kiefer, Past Global Changes International Project Office, Sulgeneckstrasse 38, CH-3007 Bern, Switzerland.

M. Kienast, Department of Oceanography, Dalhousie University, 1355 Oxford Street, Halifax, NS, Canada B3H 4J1.

T. F. Pedersen, School of Earth and Ocean Sciences, University of Victoria, Petch Building 168, P.O. Box 3055 STN CSC, Victoria, BC, V8W 3P6 Canada. 